\title{
The effect of rainfall variability and landuse/land cover change in a small tropical river basin in Kenya
}

\begin{abstract}
The study to determine the impacts of land use/land cover change and rainfall variability on river discharge was undertaken in the Thika river basin in Central Kenya highlands. The study used data on rainfall, river discharges as and landuse/ land cover change for the period 2000-2015 to determine hydrologic changes in the basin. Landsat images were analyzed using ENVI 4.7 to determine land cover/landuse changes in the period 2000 and 2015 . The result of the study showed that natural forest cover has decreased by $1 \%$ while planted forest cover has increased by $22 \%$ due to implementation of reforestation programmes and soil conservation measures in the basin. Area under coffee plantations decreased by $38 \%$ while the area under tea plantations, urban areas (towns) and agriculture slightly increased by $4 \%, 5 \%$ and $100 \%$, respectively. Although the relationship between rainfall and river discharges in the basin is complex, there is evidence of an increase in the frequency of occurrence of above normal rainfall and river discharges. However, there has been a reduction of the peak river discharges. The study concluded that increasing trends in river discharges can be attributed to increasing trend in forest cover and rainfall in the basin. The increasing trend in rainfall can be attributed to climate change. This study recommends intensification of reforestation programme to attain a $60 \%$ forest cover. This would lead to tremendous hydrological benefits in terms of flow of the river.
\end{abstract}

Volume 3 Issue I - 2019

\author{
Johnson U Kitheka, Samuel Mwangi, Philip K \\ Mwendwa \\ Department of Hydrology and Aquatic Sciences, School of \\ Water, Environment and Natural Resources, South Eastern \\ Kenya University, Kenya
}

Correspondence: Johnson U Kitheka, Department of Hydrology and Aquatic Sciences, School of Water, Environment and Natural Resources, South Eastern Kenya University, P.O Box 170-90200 Kitui, Kenya,

Email kolbio_kolbio@yahoo.com, jkitheka@seku.ac.ke

Received: February 01, 2018 | Published: February 13, 2019

Keywords: landuse change, rainfall, river discharge, swat, arc-gis, thika river, Kenya

\section{Introduction}

Socio-economic development and landuse change associated with rapid population growth and expansion in tropical catchment areas is thought to be contributing immensely to the changes in hydrology of tropical river systems in the Kenya highlands. ${ }^{1-7}$ However, few studies in Kenya have attempted to establish the extent to which landuse changes has impacted streamflow in specific tropical river basins. ${ }^{8,9}$ This study therefore sought to fill this gap by assessing the impacts of land use change and rainfall variability on the discharge of Thika River in the Central Kenya Highlands. Thika river basin is an important source of water to about 4.5 million people. The river flows to Masinga dam reservoir which is the largest dam in Kenya that produces $70 \%$ hydro electricity in the country. Therefore, understanding the effects of rainfall variability and landuse change on streamflow in the Thika river basin is important for sustaining water supplies in rural and urban areas as well as generation of hydropower which is critical for socio-economic development in Kenya. Rainfall variations have important influences on runoff generation in the Kenya highlands. This is particularly important in view of increasing variability of rainfall in Central Kenya due to climate change. The establishment of how land use change in recent past have affected the stream flow of the Thika river is important in the formulation of the watershed management strategies. It is also important for determining how streamflow changes in the Upper Tana Basin could affect the Kenya's largest and most important river system - the Tana River which flows to the Indian Ocean. Severe sedimentation in Masinga dam (Kenya's largest) in recent times has raised concern on how land use change in larger upper Tana Basin could affect the generation of hydropower in the Tana river system. Sedimentation in the Masinga dam is of the order $11.0 \times 10^{6} \mathrm{~m}^{3}$ and this has reduced the design capacity by more than $15 \%$ (Mutua et al., 2005). The sources of sediments discharged in to the reservoir are located in the Upper Tana Basin that includes the Thika sub-basin.
Drivers of land use change in the Thika river basin have not been established in previous studies. However, these can be traced at both local, national and international levels. Fall of international market of some cash crops such as coffee have led to the conversion of coffee plantations into real estates and horticultural areas mostly in lower zone of the Thika catchment. Uncontrolled urbanization due to rapid population growth and expansion in the basin is pushing people into areas that were previously under agriculture. This has led to conversion of agricultural areas into other land uses. In the recent past there has been attempts by several non- governmental organizations, governmental institutions to reverse the degradation of the Thika catchment through financing of water and soil conservation measures such as planting of trees (mostly exotic), soil erosion control and awareness creation among the local community. The Green Water Credit mechanism that pays rural communities for specific land and soil management activities has also been implemented in the basin. ${ }^{10-12}$ However, the impacts of Green Water Credit Mechanism have not been evaluated. This study used Soil and Water Assessment Tool to determine the relationship between rainfall and river discharge (see also Gasman, 2007). The main objective of the study was to determine the influence of rainfall; land use and land cover changes on stream flow of Thika River.

\section{The study area}

\section{Location}

Thika sub-basin is located between latitude $36^{\circ} 35^{\prime} \mathrm{E}$ and $37^{\circ} 35^{\prime}$ $\mathrm{E}$ and longitude of $0^{\circ} 35^{\prime} \mathrm{S}$ and $1^{\circ} 10^{\prime} \mathrm{S}$. The total basin is $194 \mathrm{~km}^{2}$. The basin forms part of larger upper Tana River Basin which supplies water to Kenya's largest river system -the Tana river. The land generally slopes in eastern direction with altitude varying from 1,465 $\mathrm{m}$ above sea level (asl) at the Masinga dam outlet and 2,844 $\mathrm{m}$ a.s.1 in the Aberdare Mountain Range. Thika river originates from eastern slopes of Aberdare Mountain Range and flows south eastward for 100 
$\mathrm{km}$ before joining Chania river to form Thika main river near Thika town. Thika main river then flow for about $100 \mathrm{~km}$ before it drains into Masinga reservoir. Within the catchment is found the Ndaka-ini Dam which is managed by Nairobi City Water and Sewerage Company. The dam has a surface area of $3 \mathrm{~km}^{2}$ and depth of $60 \mathrm{~m}$ and the design capacity is 70 million $\mathrm{m}^{3} .^{13}$

\section{Social-economic activities}

Most people in the Thika sub-basin are farmers carrying out smallscale farming as the main livelihood activity. On the upper slopes of Aberdare Range, tea is the main cash crop grown and maize, bean and potatoes are the main subsistence crops. In the middle reaches of the sub basin, coffee and maize are grown in addition to agroforestry. In the mid lower zones, pineapple plantations and urbanization are important landuses in this area. There are also several small to medium towns located along the mains road with largest town being Thika (FAO, 2004).

\section{Climate}

The Thika basin is characterized by altitude dependent agroclimatic zones which generally ranges from humid to semi arid zones. The rainfall distribution is bimodal with long rainy season occurring between the months of March and May and short rainy season occurring between the months of October and December (Figure 1). The total annual rainfall varies from $800 \mathrm{~mm}$ in the lower region of the basin (altitude: $1,525 \mathrm{~m}$ a.s.l) to $2,200 \mathrm{~mm}$ in the upper region of the basin (altitude: $2,600 \mathrm{~m}$ a.s.l). Temperature is high in lower semi arid zone ranging from $25^{\circ} \mathrm{C}$ to $30^{\circ} \mathrm{C}$. However, temperatures in the upper mountainous region range between $18^{\circ} \mathrm{C}$ and $20^{\circ} \mathrm{C}$. February is the hottest month while July is the coldest month. The annual potential evaporation ranges from $1250 \mathrm{~mm}$ in the upper mountainous zone (at altitude of $2400 \mathrm{~m}$ a.s.1) to $1800 \mathrm{~mm}$ in the semi arid zone at altitude of $1100 \mathrm{~m}$ a.s.1.

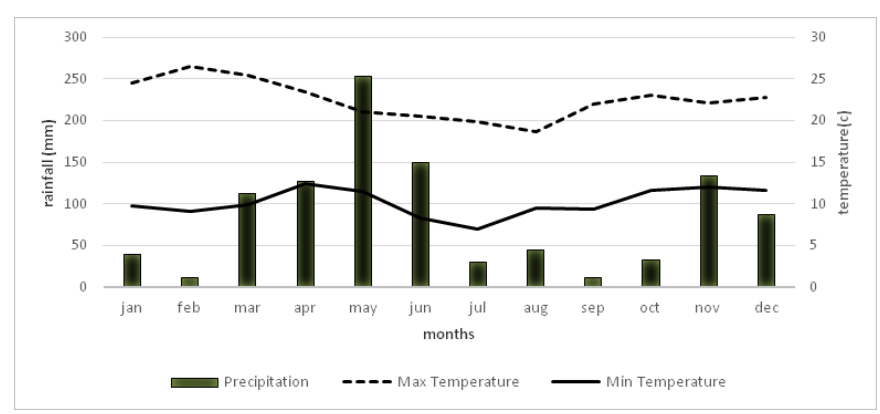

Figure I The monthly average temperature and rainfall in the Thika sub-basin.

\section{Soils}

Soil in the catchment varies with elevation and rock parent materials. Soils in Aberdare Ranges forest range from deep to very deep reddish brown, friable clay, with acidic humic topsoil (andohumic). Soils in the tea growing areas is imperfectly drained, deep, dark grayish brown molted firm clay underlying thick topsoil of silty clay loam. These soils are mainly solodic and planosols. In the middle zones of the basin where small-scale farming is mostly practiced, the soils are deep dark reddish brown to dark brown friable clay with acidic humic top soils (nitisols and andosols).

\section{Geology}

The basin is covered by rocks of the upper Athi series which formed from successive lava flows in the post rift valley formation in upper zones. It also comprises volcanic rock, tertiary and Pleistocene rocks, which are underlain by gneisses of the Basement complex. The stratigraphy is defined by Athi series which overlie the Kapiti phonolite which subsequently overlie the Basement complex rocks of the Mozambique belt.

\section{Population}

The population in the basin is estimated to be 472,334 according to the 2009 National Population Census (NPC, 2009). Approximately $50 \%$ of the population is within the age bracket $15-64$ years and $31 \%$ of people fall into the 15-30 age bracket. The population densities are generally some of the highest in Kenya varying from 250 people $/ \mathrm{km}^{2}$ in the lower zones of the basin to 500 people $/ \mathrm{km}^{2}$ in higher altitude areas (NPC, 2009).

\section{Methodology}

\section{River discharge and rainfall data}

The river discharge data obtained from the Water Resources Management Authority (WARMA) based on daily measurements made at River Gauging Station (RGS) 4CB05. For this river gauging station data was available from 2000 to 2015. Rainfall data was obtained for three stations-Gatare forest station, Githumu high school and Thika dam. These data were obtained from Kenya Meteorological Department (KMD) and Thika dam station. ${ }^{14}$

\section{Land use/land cover maps}

Land use and land cover maps were used to determine the spatial extent and classification of land use and land cover classes in the basin (Table 1). LULC data combined with soil data was used to determine hydrological characteristic of the catchment. The land use/land cover maps were obtained from International Livestock Research Institute (ILRI) in Nairobi. ${ }^{12}$

\section{Land use/cover change analysis using Landsat images}

The Landsat images band 1and 3, and 4 for TM and TM+ were obtained from earth explorer website. The Thika basin falls under path 168 and row of 61 . The image was geo-referenced and corrected for any sensor irregularity. Seven (7) land cover/use classes were adopted in image classification. Preprocessing of satellite images prior to image classification and change detection comprised a series of sequential operations, including atmospheric correction or normalization, image registration, geometric correction, and masking for clouds, water, irrelevant features. The images used had already been geo-referenced and corrected for all sensor irregularity. The two Land sat images were imported to the Arc GIS where the study area was extracted by use of mask tool. The image was transferred to ENVI 4.7 for image classification and land use changes analysis. Bands 1, 2 and 3 were combined to give false color of red, green and blue to give false color as shown in Table 1 below. After compositing, training sites were identified so that image classification tool in ArcGIS tool can identify areas with same signature in the image. Areas with similar signature represented various land cover/landuse. Further information on the catchment landuses was acquired by ground truthing where various land covers were identified in the field.

Aberdare range forest is the only natural forest in the catchment and hence it was used in the land use land cover scenario analysis. The hydrological impact of the possible extent of future forest cover 
was conducted by assuming that decrease in forest cover was due to increase in agriculture and urbanization. The increase in forest cover was attributed to proportional decrease in the area occupied by the agricultural fields and urban areas. Four different scenarios were defined. Each scenario was characterized by a different magnitude and direction of the forest cover and agricultural land change.

Table I The land cover classification adopted in this study

\begin{tabular}{lll}
\hline No. & Land cover class & Description \\
\hline 1 & Water & Areas with open water as dam/no vegetation \\
2 & Forest & Trees with $7-40 \mathrm{~m}$ tall with interlocking canopy they are evergreen throughout the year \\
3 & Coffee & Small trees of $6 \mathrm{~m}$ with canopy covering only $20 \%$ \\
4 & Agriculture & Small areas where season crop like maize are grown \\
5 & Tea & Are plantation with interlocking canopy which is evergreen \\
6 & Pineapple & Large scale farming low lying crop which irrigated \\
7 & Built area & Ares under homes Standing building and green houses \\
\hline
\end{tabular}

\section{Results}

\section{Variability of River discharge}

Thika River shows significant seasonal and inter-annual variability of river discharge. In the period between the years 2000 and 2015, the mean river discharge was $64 \mathrm{~m}^{3} / \mathrm{s}$ and the maximum river discharge is $353 \mathrm{~m}^{3} / \mathrm{s}$. The mean rainfall in the basin was $91 \mathrm{~mm}$ and the maximum rainfall was $719 \mathrm{~mm}$. The low river discharges were generally more frequent as compared to high flows since these occurred 75 to $85 \%$ of the time. Figure 2-4 shows the variations of the monthly river discharge and rainfall in the period between the years 2000 and 2015. The highest river discharges were normally observed in the rainy season months in the period between March and May and also in the period between October and December. The lowest river discharges occurred in the dry season in the period between months of December and February and also between July and October. The relationship between river discharge and rainfall exhibited a weak relationship with $\mathrm{R}^{2}$ of 0.26 (Figure 5). Therefore, rainfall in the basin is not a good determinant of river discharge. This indicates that other factors in the basin such as water abstraction, landuse, land cover and the nature of river channel. However, in the period between 2000 and 2015 , there was a general increase in both river discharge and rainfall (Figures 3) (Figure 4). The river discharge and rainfall increased at a rate of $0.004 \mathrm{~m}^{3} / \mathrm{s}$ per year and $0.19 \mathrm{~mm}$ per year, respectively. These increases were however not significant as the correlation coefficient $r$ and coefficient of determination $R^{2}$ were less than 0.20 and 0.10 , respectively.

Table 2 shows the deviation of rainfall and river above or below the 2000-2015 mean monthly values of $91.08 \mathrm{~mm}$ and $64.16 \mathrm{~m}^{3} / \mathrm{s}$, respectively. There is evidence of change in the frequency of occurrence of below and above average rainfall and river discharge in the basin. In the period between 2000 and 2015, the frequency of occurrence of below average rainfall increased by $-33 \%$ while that for the above average rainfall increased by $10 \%$. In the same period, the frequency of occurrence of below average river discharge decreased by $-23 \%$ while the occurrence of above normal river discharges increased by $19 \%$. These results show that the frequency of occurrence of below normal rainfall and river discharges is decreasing while that of the above normal rainfall is increasing. This could be attributed to climate change. The results also showed that since the year 2009, there has been an increase in extreme rainfall and river discharge variability.
The peak river discharges showed a decreasing trend in the period between 2000 and 2009. The peak river discharges in the period after 2009 are relatively lower than those measured in the period between 2000 and 2009.

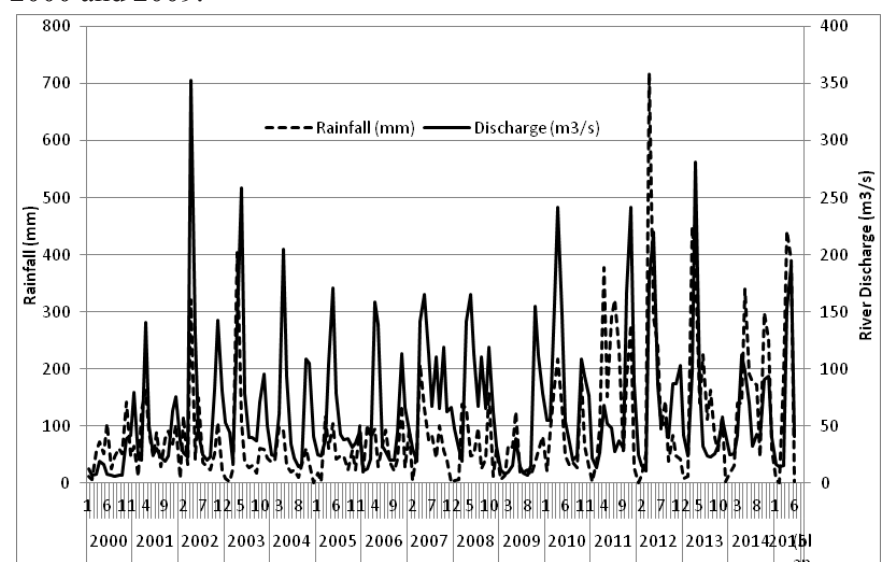

Figure 2 The variations of Thika River discharge in the period between 2000 and 2015 .

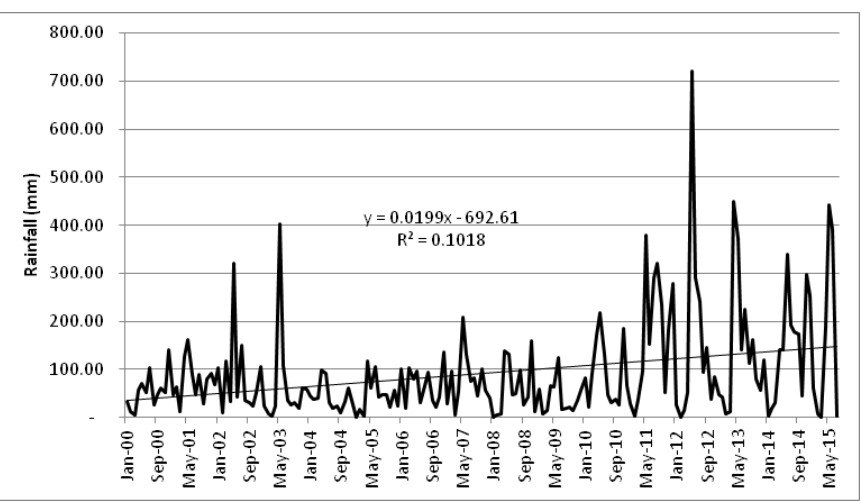

Figure 3 The variations of rainfall in the period between 2000 and 2015 .

Figure 6 shows the relationship between river discharges, rainfall and groundwater flow in the Thika basin in the period between 2000 and 2015. The basin has relatively high surface runoff response. The peak surface runoff occurred in the same periods as the peak rainfall. However, groundwater flow and river discharge shows a significant 
phase lag with rainfall. This phase lag represents time of concentration for the river discharge and time taken for infiltrated water to reach the groundwater aquifers. The groundwater flow therefore reached maximum value about a month after the highest rainfall. This is due to the fact that the percolated water takes time to reach the groundwater aquifer. The groundwater aquifer subsequently releases groundwater gradually to the river particularly during the dry seasons when the effect of rainfall is absent.

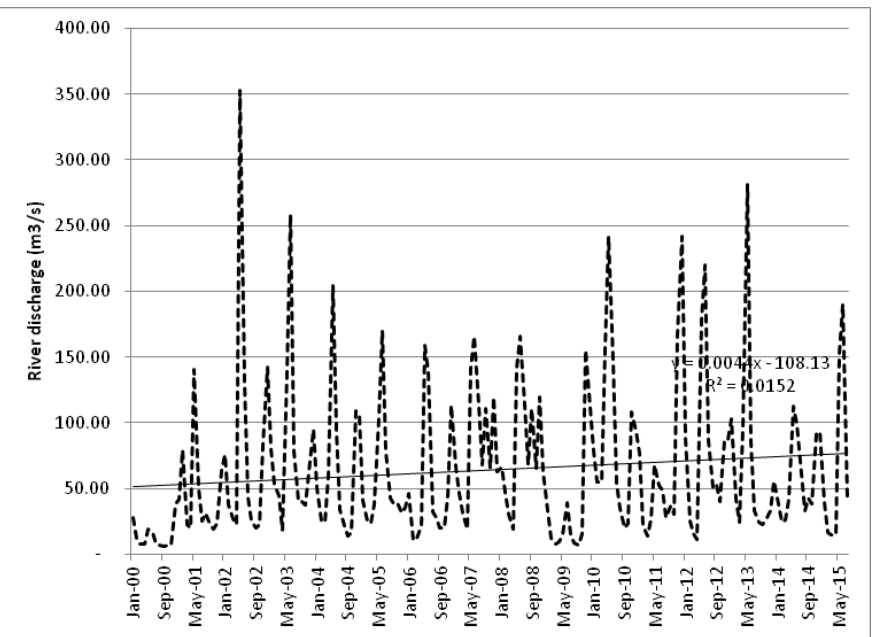

Figure 4 The variations of river discharge in the period between 2000 and 2015.

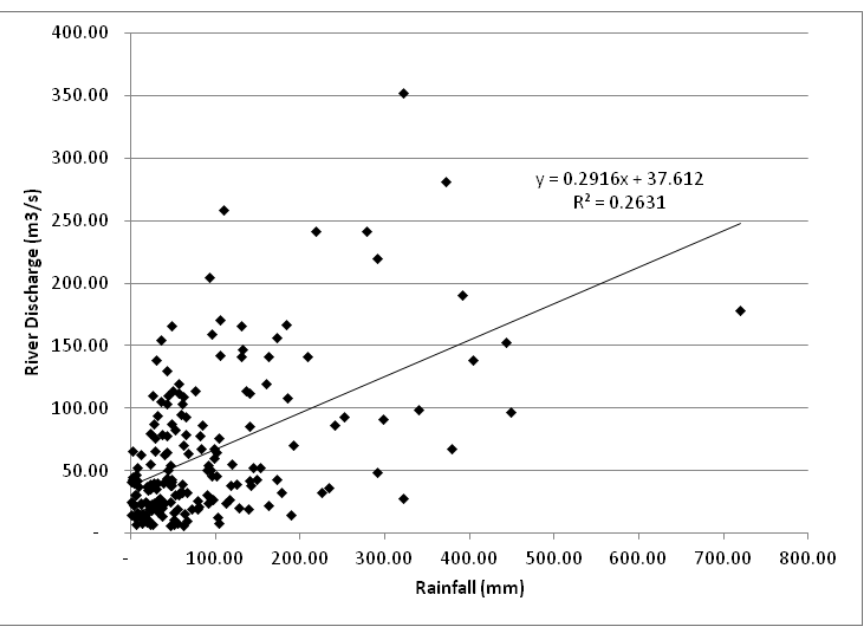

Figure 5 The relationship between rainfall and river discharge in the period between 2000 and 2015 .

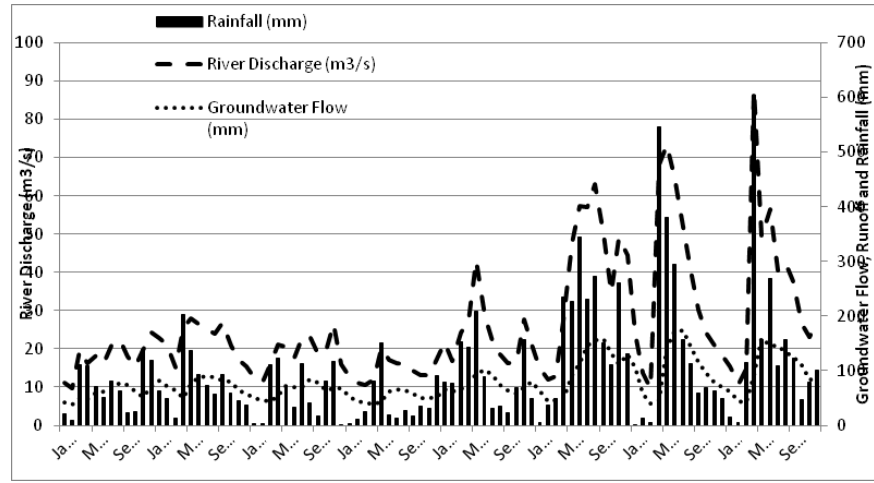

Figure 6 The variations of rainfall, river discharge and ground water flow in the Thika sub-basin in the period between 2000 and 2015.
Table 2 The frequency of occurrence of above and below normal rainfall and river discharge in the period 2000-2015

\begin{tabular}{lllll}
\hline Period & \multicolumn{2}{l}{ Rainfall deficit } & \multicolumn{2}{l}{ Discharge deficit } \\
\hline & $\begin{array}{l}\text { Above } \\
\text { mean }\end{array}$ & $\begin{array}{l}\text { Below } \\
\text { mean }\end{array}$ & $\begin{array}{l}\text { Above } \\
\text { mean }\end{array}$ & $\begin{array}{l}\text { Below } \\
\text { mean }\end{array}$ \\
\hline $2000-2004$ & 14 & 46 & 17 & 43 \\
$2005-2009$ & 20 & 53 & 30 & 42 \\
$2010-2015$ & 24 & 31 & 21 & 33 \\
$\%$ Change & $10 \%$ & $-33 \%$ & $19 \%$ & $-23 \%$ \\
Trend & Increase & Decrease & Increase & Decrease \\
\hline
\end{tabular}

\section{The effects of land use and land cover change}

The analysis of the effects of land-cover change on river discharge were based on the comparison of the model results from the group of experiments using different land covers and from those of the control run which used the land-cover in year 2000. The scenarios were used to evaluate the effects of landuse change. In this study, scenario 1 represented landuse in the year 2000 and Scenario2 represents land use in the year 2016. Both scenarios yielded significant changes in water yields, with Scenario2 yielding relatively higher river discharges than Scenario1 (Figure 7). The analysis of landuse maps generated using Landsat images of TM and TM+ by ENVI 4.7 showed that there has been a significant change in landuse in the Thika sub-basin (Figures 8) (Figure 9). Table 3 provides details on the extent of landcover and landuse change. In the period between the years 2000 and 2016, the forests and shrub cover in the basin increased by $23 \%$. At the same time, land under agriculture increased by about $5 \%$. The built up areas increased by $35 \%$. While land under tea crop increased marginally by about $5 \%$, that under coffee decreased by $38 \%$. The area under coffee has presumably been taken over by built up area.

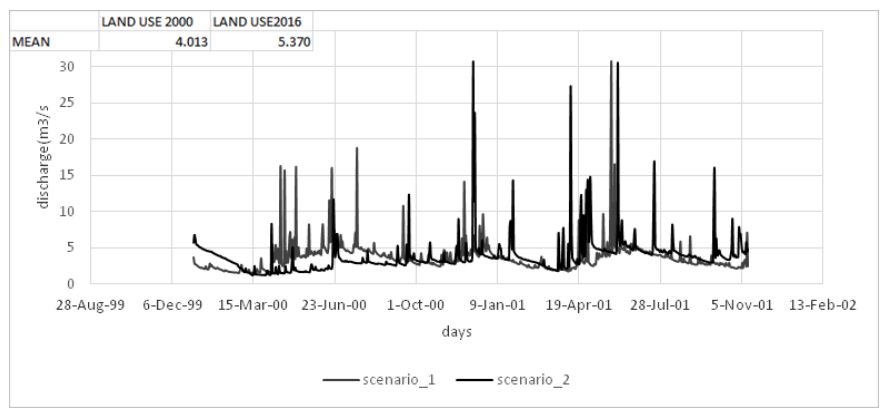

Figure 7 The comparison of the influence of different land use on the Thika River discharges in the period between 1999 and 2002.

Table 3 Land use change in Thika sub-basin based on landsat image analysis

\begin{tabular}{llllll}
$\begin{array}{l}\text { Land use/ } \\
\text { cover }\end{array}$ & $\begin{array}{l}\text { Land use } \\
\text { in 2016 } \\
\text { (Ha) }\end{array}$ & $\begin{array}{l}\text { land use } \\
\text { in 2000 } \\
\text { (Ha) }\end{array}$ & $\begin{array}{l}\text { Change } \\
\text { (Ha) }\end{array}$ & $\begin{array}{l}\text { \% } \\
\text { Change }\end{array}$ & Remark \\
\hline $\begin{array}{l}\text { Water } \\
\text { Forest and } \\
\text { shrub land }\end{array}$ & 2016.32 & 265.4 & 0.08 & 0.03 & No change \\
Agriculture & 7402.68 & 7050.6 & 352.08 & 4.76 & Increase \\
Pineapple & 4116.29 & 4118.31 & 1258.02 & 0.98 & No change \\
Coffee & 5211.81 & 7213.23 & 2001.42 & 38.4 & Decrease \\
Tea & 5630.04 & 5352.66 & 277.38 & 4.93 & Increase \\
Built up & 6255.72 & 4093.47 & 2162.25 & 34.56 & Increase \\
\hline
\end{tabular}




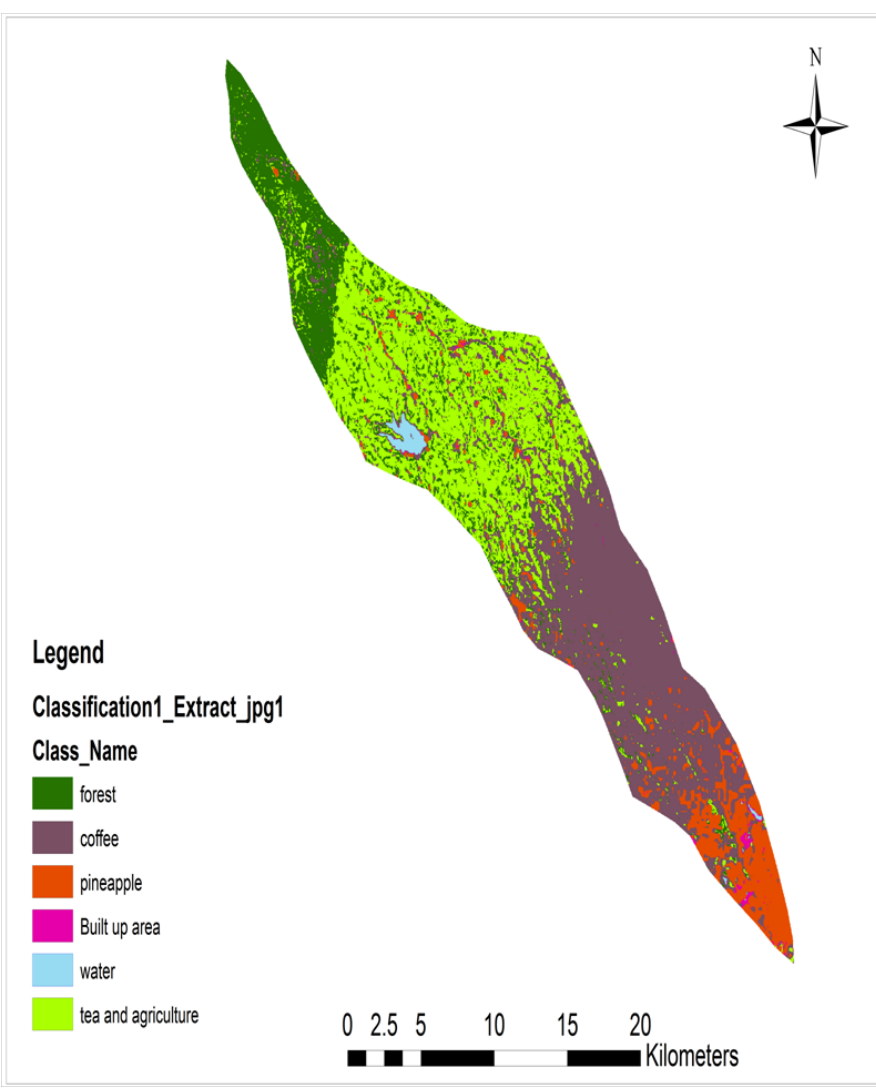

Figure 8 Land use in Thika river basin in the year 2000.

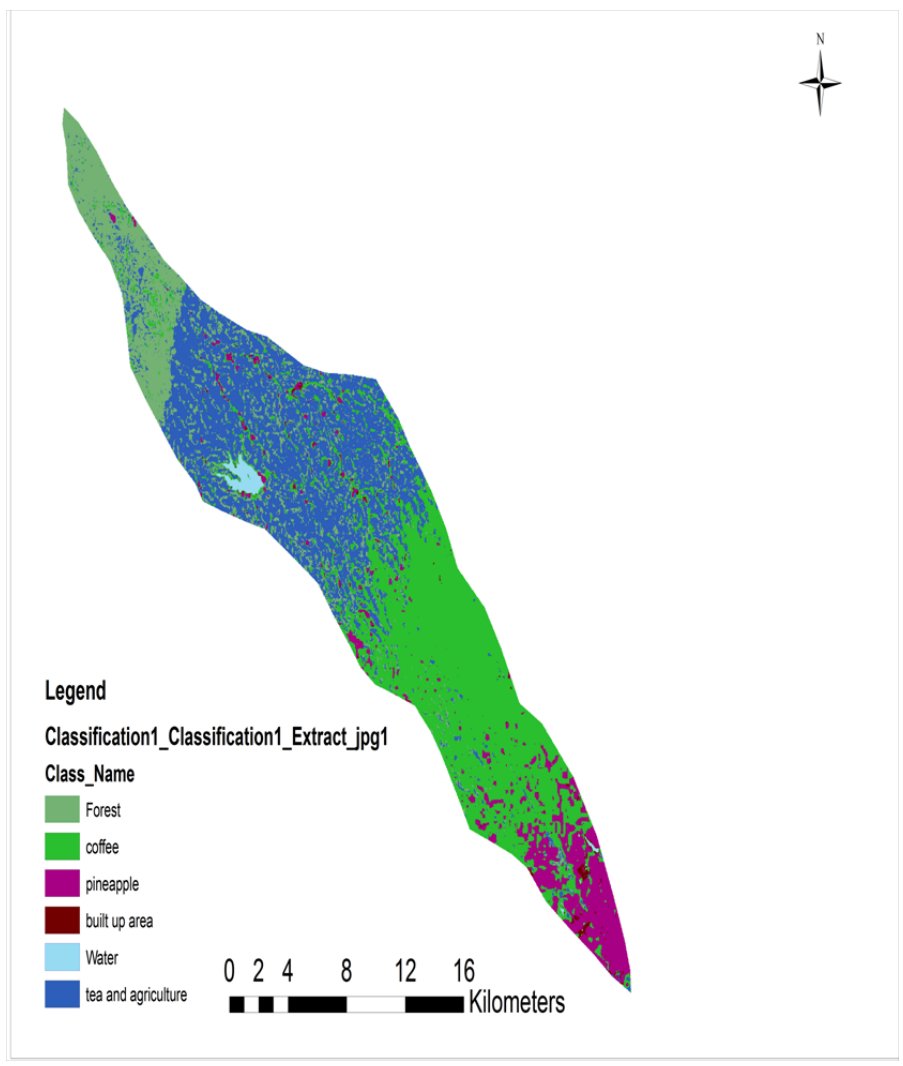

Figure 9 Land use type in Thika river basin in the year 2016.

\section{Discussion}

\section{Changes in river discharges and rainfall}

There is a significant change in rainfall and river discharges in the Thika river basin, based on data for the period between the year 2000 and 2015. The river discharge in the river basin has been increasing steadily with mean annual increase of $4.34 \mathrm{~m}^{3} / \mathrm{s}$ in year 2000 and $5.34 \mathrm{~m}^{3} / \mathrm{s}$ in year 2015. This increase in river discharge is consistent with an increase in rainfall over the same period. The frequency of occurrence of above normal rainfall and river discharges has increased by $10 \%$ and $19 \%$, respectively. On the other hand the frequency of occurrence of below normal rainfall and river discharges has decreased significantly by $33 \%$ and $23 \%$, respectively. The magnitude of peak river discharges has however declined. The general increasing trend in mean river discharges (and decreasing peak flows) can therefore be attributed to increasing above normal rainfall coupled with increasing forest cover in the basin. Previous studies have shown that an increase in forest cover by $60 \%$ would result in doubling of the current river discharge in the basin. ${ }^{15}$

While the results of the study showed that increase in river discharge is consistent with the increase in rainfall in the basin in the period 2000-2015, the lag between the two parameters explains the weak statistical relationship. The river discharge variations are also influenced by landuse/land cover, drainage density, presence of water reservoirs, water abstraction, basin slope and soil characteristics. In the recent past, increased abstraction and diversion of river water for domestic and irrigation uses has further modified the flow character of the river. The relationship between rainfall and river discharge was represented by a linear regression equation of the form $\mathrm{Qf}=0.2916 \mathrm{Rf}+37.61$ in which $\mathrm{Rf}$ is rainfall $(\mathrm{mm})$ and $\mathrm{Qf}$ is river discharge $\left(\mathrm{m}^{3} / \mathrm{s}\right)$. An increase of rainfall by $1 \mathrm{~mm}$ leads to a corresponding increase in river discharge by $0.29 \mathrm{~m}^{3} / \mathrm{s}$. Studies done on Yala River in Western Kenya derived a similar regression equation (UNESCO, 2005). However, the value of this equation is limited due to low statistical significance as demonstrated by low $\mathrm{R}^{2}$ value of 0.26 .

\section{Change in land use and land cover}

The Thika River basin has in a period of 16 years (2000-2016) undergone a tremendous changes in landuse and land cover. There has been an increase in the area under forests and shrubs, and agriculture. While the area under tea increased marginally, that under coffee plantations decreased tremendously. The area that was once under coffee plantations has been converted into built up area. The increase in forest cover by $22 \%$ could be a result of reforestation programmers that have been implemented in the basin. In the last 15 years, there has been increased attention given to the basin by government, private sectors and locals who have implemented reforestation projects in order to protect the water catchment areas of Ndaka-ini dam (Thika Dam) which supplies water to the City of Nairobi. For example Ndaka-ini half marathon which is held annually has raised funds that led to planting of 10,000 tree seedlings annually for the last 13 years. The increase in the area under tea plantation by $5 \%$ could be due to better prices paid to farmers. Tea remains Kenya high foreign income earning cash crops and the local communities have increased tea in some areas that were once covered by coffee farms. The major decrease in the area under coffee plantation by $38 \%$ can be attributed to fall in the price of coffee in the international market in 1990s that has led to uprooting of the crop. These results compares well with those of Kagira ${ }^{15}$ who showed that the areas under forest by $32 \%$ The area under water body has remained unchanged as there has not been 
construction of additional reservoirs since 1992 when Thika dam was built. The major increase in the built up area can be attributed to rapid population increase and expansion in the basin. More houses have been built to accommodate more people in rural and urban areas. This has also been attributed to increased land sub-division. Some coffee plantations near Thika town have been converted into real estate.

While reforestation programmes have been successful in the upper zones of the basin, the situation has been unsatisfactory in the lower semi arid zones of the basin. Previous studies in the Upper Tana catchment have shown that reforestation in the semi arid zone below $1,850 \mathrm{~m}$ is difficult due to low rainfall amounts and high livestock and human populations (see also Jennifer et al, 2005). However, reforestation in the upper zones at an elevation between $2,000 \mathrm{~m}$ and $1,850 \mathrm{~m}$ can result in a 30 to $55 \%$ increase in reforested area in the Upper Tana River catchments. Some studies have shown that full reforestation up to an altitude of $1,850 \mathrm{~m}$ would result in a $7 \%$ decrease in sediment loading in the Masinga Reservoir (Jennifer et al, 2005).

\section{Effects of land use and land cover on river discharge}

The land use/land cover change in the Thika river basin has had significant impact on river discharges. The increase in forest cover and area under tea plantation has led to the stabilization of streamflow as the high vegetation cover intercepts rainfall, reduces surface runoff generation and facilitates high infiltration of rainfall into the ground. The infiltrated water is eventually released slowly into the river channel. The lag between rainfall occurrence and river discharge can partly be explained by the long time it takes water to flow into the river channel. Previous studies have shown that if the area under tea plantations and forest cover in the basin is increased to $60 \%$, this would lead to a $100 \%$ increase in river discharge and more uniformly distributed streamflow throughout the year. ${ }^{15}$ A $100 \%$ forest cover would decrease the current sediment yield by $30 \%$, while a decrease in forest cover of $20 \%$ would increase sediment yield by $40 \%{ }^{15}$ The land-use and land-cover changes can modify the magnitude and frequency of flood in the basin..$^{16}$ Different landcover patterns in the basin can cause increases or decreases of stream flow in different seasons, even though the annual amount of stream flow remains nearly unchanged. Through interactions of vegetation with soil and surface waters, land-use and land-cover can modify the local hydrological cycle and exert a strong control of the annual distribution of stream flow in the basin. ${ }^{16,17}$ Some studies have shown that rainfall and temperature are the most sensitive when it comes to the simulation of river discharge while land use or land cover is the second of the main boundary condition. ${ }^{18-25}$

\section{Conclusion}

This study concluded the increasing rainfall trend and increasing landcover in the Thika river basin has led to an increasing trend in streamflow. While the magnitude of above normal rainfall and river discharge events has increased significantly, there is an indication of a decrease in the peak river discharges. Thus, the drivers of change in river discharges in the basin can be attributed to climate change and landuse/land cover change. This study therefore recommends intensification of reforestation and soil and water programmes in the upper and middle zones of the basin, since this has potential of increasing water yield in the basin.

\section{Acknowledgments}

The author's wishes to thank Kenya Meteorological Services
(KMS) and Water Resources Authority (WRA) for providing rainfall and river discharge data used in this paper.

\section{Conflicts of interest}

The authors declare that there is no conflicts of interest.

\section{References}

1. Ongwenyi G. Problems of land use and water resource management in the upper Tana catchment in Kenya. In: Lundqvist J, et al, Editors. Strategies for river basin management. D.Reidel Publishing Co., Dordrecht, Holland. 1985;123-130.

2. Schneider H, Brown T. Remote sensing and GIS studies of erosion potential for catchment management: A densely populated agricultural catchment in Kenva. In: Harper \& Brown T, Editors. The sustainable management of tropical catchments. John Wiley \& Sons. Indianapolis. 1998;31-47.

3. Mutisya D, Mutiso S. Socio-economic aspects of subsistence farming and soil erosion in tropical catchments: The Tana Catchment, Kenya. In: Harper \& Brown, Editors. The sustainable management of tropical catchments. John Wiley \& Sons. Indianapolis. 1998;50-59.

4. Pacini ND, Harper, Mavuti K. Hydrological and ecological considerations in the management of a catchment controlled by a reservoir cascade: The Tana River, Kenya. In: Harper D \& Brown, et al. The sustainable management of tropical catchments. John Wiley \& Sons. Indianapolis. 1998;239-258.

5. Schneider HM. Sediment sources to Masinga Dam: Land and Water Management in Kenya. In: Gichuki FN, Editors. Soil and Water Conservation Branch, Ministry of Agriculture and Rural development, Nairobi, Kenya. 2000.

6. Maingi JK, March SE. Assessment of environmental impacts of river basin development on the riverine forests of eastern Kenya using multitemporal satellite data. Int J Remote Sensing. 2001;22:2701-2729.

7. Maingi JK, Marsh SE. Quantifying hydrologic impacts following dam construction along the Tana River, Kenya. $J$ Arid Environment. 2002;50(1):53-79.

8. Mutie SM, Mati BM, Home PG, et al. Evaluating land use change effects on river flow using USGS Geospatial stream flow model in the Mara river basin, East Africa. A paper presented during the second Workshop of the EARSeL SIG on Remote Sensing of Land Cover, Bonn, Germany. 2006;1-8.

9. Kigira FK, Gathenya JM, Home PG. Modelling the influence of land use changes on sediment yield and hydrology in Thika River Catchment. Proceedings of 2007 JKUAT Scientific, Technological and Industrialization Conference, JKUAT, Kenya. 2008;1-5.

10. Hunink JE, Immerzeel WW, Droogers. Green Water Credits for the Upper Tana Basin, Kenya, Phase II -Pilot Operations: Biophysical assessment using SWAT. Report Future Water. 2009.

11. Hunink JE, Immerzeel WW, Drudgers P, et al. Green Water Credits for The Upper Tana Basin, Kenya. Phase II - Pilot Operations: Biophysical assessment using SWAT. ISRIC. 2010;1-81.

12. Wilschut LI. Land use in the Upper Tana. Technical report of a remote sensing based land use map. Green Water Credits Report 9 / ISRIC Report 2010/03. 2010.

13. Shisanya C, Moriasi D, Steiner J, et al. Fort Cobb Reservoir Watershed, Oklahoma and Thika River Watershed, Kenya twinning pilot project. American Geophysical Union Fall Meeting, San Francisco, California. $2007 ; 88(52)$.

14. Kenya Meteorological Department. Climatological statistics for Kenya. Nairobi: Kenya Meteorological Department. 1984. 
15. Kagira FK. Modeling the influence of land use changes on water and sediment yield in the Thika river catchment using SWAT model. MSc Thesis, JKUAT, Kenya. 2007.

16. Hua Gou, Qi Hu, Tong Jiang. Annual and seasonal stream flow response to climate and land cover changes in Poyang lake basin, China. Journal of hydrology. 2008;355(1-4):106-122.

17. Kimaro TA, Tachikawa YY, Takara. Evaluating land use changes effects on floods peak using distributed rainfall runoff model in Yasu River, Japan. Annual Disaster Prevention Research Institute, Kyoto University, No 46 B. (2003). 2001;282:1-8

18. Batjes NH. Soil property estimates for the Upper Tana River catchment Kenya, derived from SOTER and WISE (SOTWIS-Kenya Upper Tana, ver. 1.1). Report 2010/07b, ISRIC - World Soil Information Wageningen (41p.withdataset). 2011;36.

19. ESRI. ArcGIS Desktop: Release 10.1 Environmental Systems Research Institute Redlands. 2012.
20. Winchell M, Sprinivasan R, Luzio M, et al. ARCH SWAT interface for SWAT 2012 user's guide Blackland and Research and Extension Center. 2013.

21. Lambrechts C, Bongo W, Collins C, et al. Aerial Survey of Destruction of the Aberdare Range Forest. Division of Early Warning and Assessment, United Nations Environment Programme, Nairobi, Kenya. 2003;1-53.

22. Maingi JK. Sedimentation in Masinga Reservoir. Unpublished M.Sc. Thesis. University of Nairobi, Kenya. 1991.

23. Nash JE, Sutcliffe JV. River flow forecasting through conceptual models Part I: A discussion of principles. J Hydro. 1970;10(3):282-290.

24. Neitsch SL, Arnold JG, Kiniry JR, et al. Soil and Water Assessment Tool: Theoretical Documentation. ATM. 2002.

25. Ongwenyi GS. Erosion and sediment transport in the upper Tana catchment, with special reference to the Thiba basin. PhD thesis, University of Nairobi. 1978. 